\title{
Penerapan Model Vogel Approximation Method Untuk Optimalisasi Rute Perbaikan Access Point Berdasarkan Biaya (Studi Kasus PT XYZ)
}

\author{
Muhammad Anwari ${ }^{1}$,Husni Mubarok ${ }^{2}$,Heni Sulastri ${ }^{3}$ \\ ${ }^{1,2,3}$ Porogram Studi Informatika Universitas Siliwangi \\ ${ }^{1}$ m.anwari@gmail.com, ${ }^{2}$ husnimubarok@unsil.ac.id, ${ }^{3}$ henisulastri@unsil.ac.id
}

\section{INFORMASI ARTIKEL}

Sejarah Artikel:

Diterima Redaksi:

Revisi Akhir:

Diterbitkan Online:

\section{KATA KUNCI}

Vogel Approximation Method (VAM)
Access Point
Transportasi
Teknisi
KORESPONDENSI

Telepon: +628112129190

E-mail: henisulastri@unsil.ac.id

\begin{abstract}
A B S T R A $\mathbf{K}$
Kebutuhan internet pada masa sekarang menjadi kebutuhan utama. Perusahaan penyedia internet seperti PT. XYZ memiliki ribuan produk access point, seiring banyaknya pelanggan yang memakai produk access point maka semakin banyak juga produk yang harus dipelihara agar meningkatkan kepuasan pelanggan. Permasalahan yang dihadapi seperti penyebaran teknisi ke tempat gangguan access point dan menemukan biaya transportasi seminimum mungkin. Tujuan penelitian ini yaitu untuk menemukan cara pengiriman teknisi dari tempat teknisi ke tempat gangguan sehingga semua kebutuhan terpenuhi tetapi dengan biaya yang seminimum mungkin. Metode yang digunakan untuk memecahkan masalah ini adalah metode transportasi Vogel Approximation Method (VAM), metode VAM lebih rumit dalam hal penyelesaian masalahnya tetapi lebih menghasilkan biaya minimum. Diperoleh hasil 58 (ribuan) untuk biaya transportasi setelah diterapkannya metode VAM. Hasil ini diperoleh dari kasus access point rusak dan memiliki status down yang berjumlah 7 access point dari dua area berbeda. Untuk data teknisi sendiri dimisalkan 7 teknisi dari dua area berbeda. Metode VAM diterapkan pada perangkat lunak berbasis web, pada pengujian white box perangkat lunak ini menunjukkan prosedur kompleksitas program yang baik dan resiko yang rendah dengan rata - rata nilai cyclomatic complexity kurang dari 10.
\end{abstract}

\section{PENDAHULUAN}

Masalah yang dihadapi perusahaan dalam melakukan kegiatan bisnis adalah dalam hal transportasi, seperti memperhitungkan biaya pengiriman barang, biaya transportasi dari titik awal ke titik tujuan. PT. XYZ merupakan perusahan

dalam bidang teknologi yang memiliki produk access point. Karena kebutuhan internet pada masa sekarang menjadi kebutuhan utama dalam hal menyelesaikan pekerjaan, maka produksi access point pun semakin bertambah, dengan bertambahnya produk maka waktu dan biaya dalam hal pemeliharaan, perbaikan produk access point juga bertambah. Permasalahan yang didapat yaitu penyebaran teknisi ke tempat gangguan dan menemukan biaya transportasi seminimum mungkin.

Tujuan penelitian ini yaitu untuk menemukan cara pengiriman teknisi dari tempat teknisi ke tempat gangguan sehingga semua kebutuhan terpenuhi tetapi dengan biaya transportasi yang minimum. Masalah dapat diselesaikan dengan menerapkan metode Vogel Approximation Method (VAM) pada perangkat lunak berbasis web sistem informasi laporan data access point. Penerapan yang dilakukan hanya sebatas menampilkan hasil total biaya minimum. Perangkat lunak ini memiliki fitur menampilkan klasifikasi data dan persentase dari hasil data mentah yang diunggah.

\section{RELATED WORK}

\begin{tabular}{|c|c|c|}
\hline Nama & Tahun & Kelebihan \\
\hline $\begin{array}{lr}\text { Dimas } & \text { Birawa } \\
\text { Maharisna, } & \\
\text { Mochammad } & \text { Al } \\
\text { Musadieq, } & \text { Heru } \\
\text { Susilo. [1] } & \\
\end{array}$ & 2017 & $\begin{array}{lr}\text { Metode } & \text { Vogel } \\
\text { diimplementasikan } & \text { dalam } \\
\text { pengalokasian beras } & \text { sebagai } \\
\text { rekomendasi } & \text { dalam } \\
\text { memecahkan masalah. } & \\
\end{array}$ \\
\hline $\begin{array}{l}\text { Lolyta Damora } \\
\text { Simbolon, Marihat } \\
\text { Situmorang, } \\
\text { Normalina } \\
\text { Napitupulu. [2] }\end{array}$ & 2014 & $\begin{array}{l}\text { Menggunakan metode Vogel } \\
\text { untuk menganalisa solusi } \\
\text { fisibel awal, dan metode } \\
\text { Modified Distribution untuk } \\
\text { menganalisa solusi optimum. }\end{array}$ \\
\hline
\end{tabular}




\begin{tabular}{l|l|l}
\hline Aridhanyati Arifin. & 2014 & $\begin{array}{l}\text { Metode Vogel digunakan } \\
\text { untuk menyelesaikan masalah } \\
\text { transportasi sehingga antara } \\
\text { ketersediaan air dan kebutuh }\end{array}$ \\
& & $\begin{array}{l}\text { air konsumen dapat berjalan } \\
\text { simultan ditengah } \\
\text { keterbatasan yang ada. }\end{array}$ \\
\hline
\end{tabular}

Berdasarkan hasil penelitian lainnya, metode Vogel diimplementasikan untuk menyelesaikan masalah transportasi. Untuk perbedaannya, metode Vogel diterapkan pada perangkat lunak atau hanya digunakan untuk perhitungan saja.

\section{METODE PENELITIAN}

Waktu dan tempat penelitian dilaksanakan selama 3 bulan yang bertempat di PT. XYZ. Usulan penyelesaian terhadap masalah yaitu dengan menerapkan metode transportasi Vogel Approximation Method pada perangkat lunak yang dibuat. Alasan menggunakan metode ini karena mendekati penyelesaian optimalnya meskipun lebih rumit penyelesaiannya dibanding metode lainnya seperti metode Barat Laut dan metode Biaya Terendah.

Metodologi penelitian yang digunakan yaitu Design and Creation, penelitian dengan metodologi Design and Creation dapat disebut merancang dan membangun mulai dari menggunakan rancangan, pemodelan, dan metode. Proses dari Design and Creation diantaranya :

a. Awareness

Bentuk pengenalan dan analisis masalah yang dapat berasal dari sumber - sumber penelitian terkait seperti studi pustaka atau melakukan wawancara langsung kepada narasumber. Pengumpulan data dilakukan dengan cara :

1) Studi Literatur

Dilakukan dengan mengumpulkan dan membandingkan penelitian terkait sebelumnya. Tentunya penelitian yang dikumpulkan terkait dengan penelitian metode transportasi Vogel.

2) Wawancara

Wawancara dilakukan langsung kepada salah satu pegawai PT. XYZ. Wawancara menggunakan pendekatan terbuka.

\section{3) Suggestion}

Saran dalam menyelesaikan masalah pada penelitian ini yaitu agar masalah rute perbaikan access point dapat optimal yaitu dengan menerapkan algoritma transportasi Vogel pada perangkat lunak yang dibangun. Penerapan metode Vogel ini dapat mengetahui biaya minimum yang dikeluarkan oleh perusahaan ketika mengirim teknisi ke tempat gangguan.

4) Development

Metode dalam membangun perangkat lunak yaitu metode Extreme Programming. Proses kerja metode Extreme Programming memiliki kerangka kerja yang terbagi menjadi 4 konteks aktivitas utama yaitu Planning, Design, Coding, dan Testing.

5) Evaluation
Evaluasi memeriksa rancangan dan hasil yang dikembangkan untuk mengurangi kesalahan dari gambaran yang diberikan. Dan juga mengevaluasi penelitian yang dilakukan apakah memiliki kekurangan atau terdapat saran yang ditambahkan.

6) Conslusion

Kesimpulan hasil dari proses seluruh penelitian yaitu mengambil kesimpulan hasil dari penerapan metode Vogel dalam menghitung optimalisasi jarak berdasarkan biaya.

\section{HASIL DAN PEMBAHASAN}

\subsection{Hasil}

a. Hasil Pengumpulan Data

Data yang terkumpul berjumlah 2539 pada bulan Januari 2018. Dari jumlah data 2539, yang dijadikan perhitungan pada metode transportasi Vogel Approximation Method hanya 7 data. Data tersebut merupakan data RSK Down dimana 4 data di area Tasikmalaya dan 3 data di area Banjar. Untuk data teknisi di misalkan 5 teknisi di area Tasikmalaya dan 2 teknisi di area Banjar.

\section{b. Hasil Perhitungan}

Perhitungan awal dilakukan dengan manual, untuk data bisa dilihat pada Tabel 2

Tabel 2. Data Gangguan dan Teknisi

\begin{tabular}{|c|c|c|c|}
\hline & Gt & Gb & TEKNISI \\
\hline $\mathbf{T t}$ & 8 & 10 & 5 \\
\hline $\mathbf{T b}$ & 10 & 8 & 2 \\
\hline GANGGUAN & & & \\
\hline
\end{tabular}

Berdasarkan tabel 2 dapat dijelaskan biaya pengiriman teknisi tasik (Tt) ke gangguan tasik (Gt) yaitu 8 dan ke gangguan banjar (Gb) yaitu 10. Untuk biaya pengiriman teknisi banjar ( $\mathrm{Tb}$ ) ke gangguan tasik (Gt) yaitu 10 dan ke gangguan banjar $(\mathrm{Gb})$ yaitu 8 .

Algortima metode transportasi Vogel Approximation Method adalah sebagai berikut :

1) Pada tiap baris dan kolom, hitunglah selisih 2 sel dengan biaya yang terkecil.

2) Tentukan baris/kolom hasil langkah (1) yang selisihnya terbesar. Jika lebih dari satu pilih sembarang.

3) Pada baris/kolom terpilih, isikan barang semaksimum mungkin pada sel dengan biaya terkecil. Hapuskan baris/kolom yang dihabiskan karena pengisian tersebut pada perhitungan berikutnya. Jika baris dan kolom terhapus bersamaan, tambahkan sebuah variable dummy.

4) Ulangi langkah $1-3$ hingga semua permintaan/persediaan habis.

5) Penyelesaian pada Tabel 3.1 dapat dilihat pada langkah berikut :

6) Pada tiap baris/kolom, hitung selisih 2 sel dengan biaya terkecil

\begin{tabular}{llc}
\multicolumn{3}{c}{ Tabel 2 Selisih Baris/Kolom } \\
\hline Baris/Kolom & $\begin{array}{c}\text { 2 Sel Biaya } \\
\text { Terkecil }\end{array}$ & Selisih \\
\hline Baris -1 & 8 dan 10 & $10-8=2$ \\
\hline Baris -2 & 10 dan 8 & $10-8=2$ \\
\hline & & Muhammad Anwari
\end{tabular}




\begin{tabular}{ccc}
\hline Kolom -1 & 8 dan 10 & $10-8=2$ \\
\hline Kolom -2 & 10 dan 8 & $10 \quad-8=2$
\end{tabular}

1) Pilih selisih terbesar dari baris/kolom, jika terdapat lebih dari satu pilih sembarang. Pada tahap ini baris/kolom terbesar dipilih pada Baris - 1 .

2) Pada baris/kolom terpilih, isikan gangguan semaksimum mungkin pada sel dengan biaya terkecil. Tabel 3 Iterasi Ke - 1

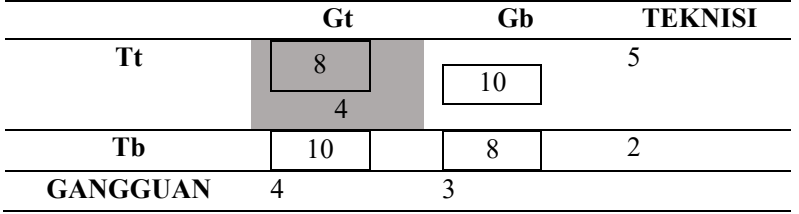

Pada iterasi ke -1 , teknisi tasik yang berjumlah 5 berkurang 4 karena digunakan untuk mengisi Gt yang jumlahnya 4. Dan untuk gangguan tasik sudah tidak memiliki gangguan lagi. Jadi untuk area tasikmalaya sudah tidak memiliki gangguan lagi.

Untuk iterasi berikutnya, ulangi langkah pertama yaitu menghitung selisih 2 sel dengan biaya terkecil, jika sel yang sudah diiisi maka tidak bisa dihitung kembali

3) Pada tiap baris dan kolom, hitung selisih 2 sel dengan biaya yang terkecil

Tabel 4 Selisih Baris/Kolom Iterasi $\mathrm{Ke}-2$

\begin{tabular}{lll}
\hline \multicolumn{1}{c}{ Baris/Kolom } & \multicolumn{1}{c}{ 2 Sel Biaya Terkecil } & \multicolumn{1}{c}{ Selisih } \\
\hline Baris -1 & Tidak dihitung & Tidak dihitung \\
\hline Baris -2 & Tidak dihitung & Tidak dihitung \\
\hline Kolom -1 & Tidak dihitung & Tidak dihitung \\
\hline Kolom -2 & 10 dan 8 & $10-8=2$ \\
\hline
\end{tabular}

4) Baris/kolom yang selisihnya terbesar terdapat pada Kolom - 2

5) Isikan barang semaksimum mungkin pada kolom -2 Tabel 5 Iterasi $\mathrm{Ke}-2$

\begin{tabular}{|c|c|c|c|}
\hline & Gt & Gb & TEKNISI \\
\hline \multirow[t]{2}{*}{ Tt } & 8 & 10 & 5 \\
\hline & 4 & 1 & \\
\hline $\mathbf{T b}$ & 10 & 8 & 2 \\
\hline GANGGUAN & & & \\
\hline
\end{tabular}

Karena gangguan di area tasikmalaya sudah tidak ada lagi dan sisa teknisi tasikmalaya berjumlah 1 dan sel yang harus diisi kolom -2 , maka sisa teknisi dari tasikmalaya harus mengisi sel gangguan dari banjar yang jumlahnya 1 . Sisa gangguan berjumlah 2 yang berasal dari area Banjar, maka isikan jumlah teknisi Banjar ke dalam sel gangguan Banjar.

Tabel 6 Iterasi $\mathrm{Ke}-3$

\begin{tabular}{c|c|cc}
\hline & \multicolumn{1}{c}{ Gt } & Gb & TEKNISI \\
\hline Tt & 8 & 10 & 5 \\
& \multicolumn{2}{c}{4} & 1 \\
\hline Tb & 10 & 8 & 2 \\
& \multicolumn{2}{c}{2} & \\
\hline GANGGUAN & 4 & 3 & \\
\hline
\end{tabular}

Setelah semua sel terisi, hitung biaya total pengiriman. Total Biaya $=(8 \times 4)+(10 \times 1)+(8 \times 2)=58$ (ribuan $)$

\subsection{Pembahasan}

a. Rancangan Perangkat Lunak

Metode dalam merancang aplikasi yaitu Extreme Programming.

6) Planning

Pada tahapan ini bertujuan untuk mendapatkan gambaran fitur dan fungsi dari perangkat lunak. Perancangan perangkat lunak menggunakan framework Laravel versi 5.5. Fitur yang dibuat diantaranya login ke sistem, unggah file berekstensi .xlsx, download file berekstensi .xlsx, pengklasifikasian data yang diolah oleh query mysql, dan penerapan metode transportasi vogel approximation method yang menjadi inti penelitian. Perangkat lunak berbasis web ini bernama Sistem Informasi Laporan Data Access Point.

\section{7) Design}

Model untuk alur kerja yang digunakan dalam merancang perangkat lunak yaitu UML (Unified Modelling Language). Menggunakan model ini karena rancangan yang dibangun terkait dengan objek.

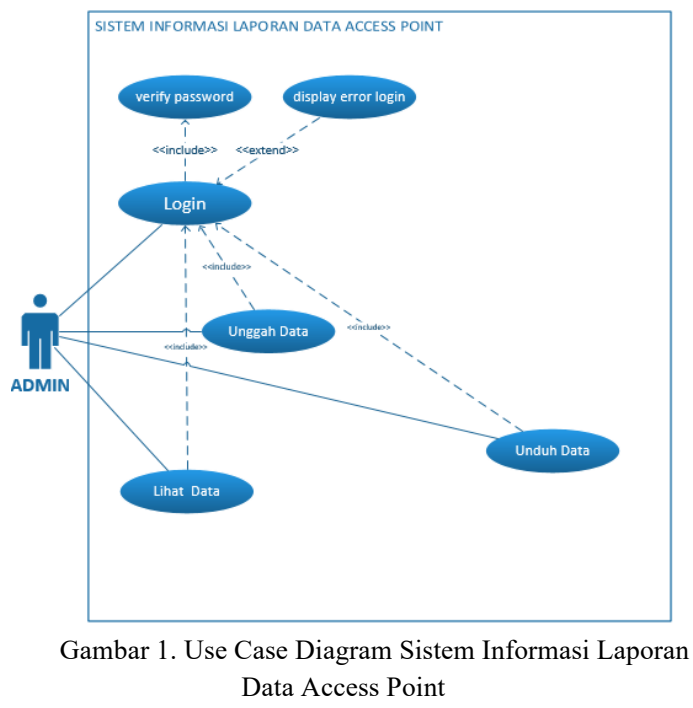

Model use case pada sistem memiliki satu aktor yaitu admin yang memiliki tugas mengolah data access point. Mulai dari login ke sistem, mengunggah data, mengunduh data dan melihat hasil presentase laporan data access point. Terdapat 6 use case yaitu use case login, verify password, display error login, unggah data, unduh data, dan lihat data.

Model untuk database memiliki 5 tabel yaitu tabel users, table gmaps_geocache, tabel aps, tabel kategori_aps, status_aps. Pada database terdapat relasi tabel antara tabel aps, tabel status_aps, dan tabel kategori_aps. Relasi ini bersifat satu ke banyak (one to many) 


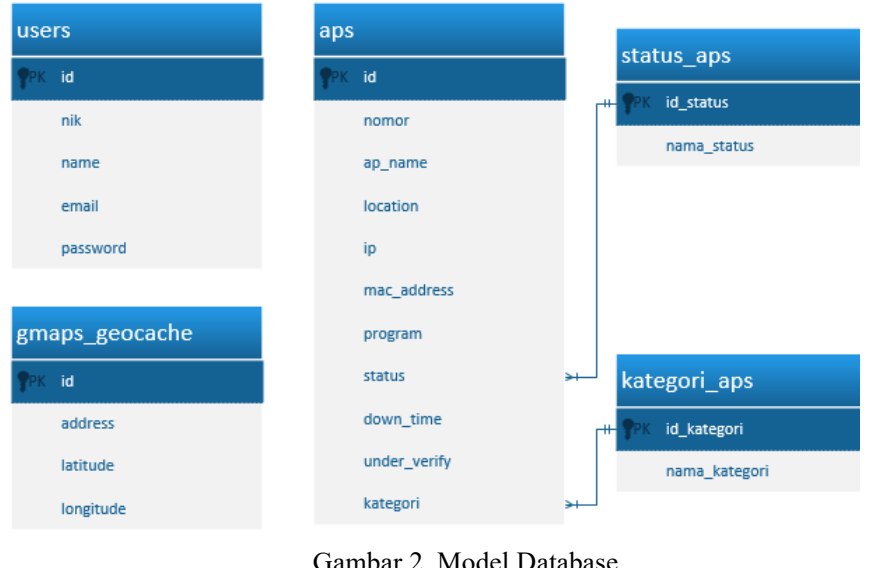

8) Coding

Tahap kode tidak dibangun dari nol karena dalam membuat perangkat lunak berbasis web ini dibuat dengan framework Laravel. Framework Laravel menggunakan bahasa pemrograman berorientasi objek, kelas, dan method. Dan juga menggunakan konsep MVC (Model, View, Controller).

\section{9) Testing}

Tahap testing menggunakan pendekatan White Box Testing dan Black Box Testing. White Box Testing merupakan pengujian yang didasarkan pada detail prosedur dan alur logika kode program, Black Box Testing yaitu melakukan pengujian dengan memfokuskan pada kebutuhan fungsional dari aplikasi.

1. White Box Testing

a. Pengujian Login

Tabel 7. Pseudo Code Pengujian Login

\begin{tabular}{ll}
\hline A0 & read(username) \\
\hline A1 & read(password) \\
\hline A2 & if(username and password) =true then \\
\hline A3 & halaman utama \\
\hline A4 & elseif \\
\hline A5 & halaman login \\
\hline A6 & endif \\
\hline
\end{tabular}

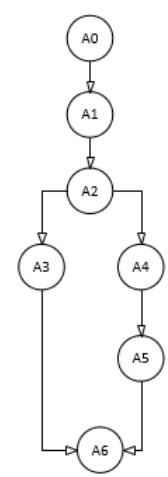

Gambar 3. Flowgraph Pengujian Login

Flowgraph dari Gambar 3 merupakan hasil dari terjemahan dari pseudo code Table VIII. Memiliki 1 percabangan, 7 node dan 7 edge.

10) Independent Path
Path $1=\mathrm{A} 0-\mathrm{A} 1-\mathrm{A} 2-\mathrm{A} 3-\mathrm{A} 6$

Keterangan Path 1 : admin memasukkan username dan password dengan benar yang kemudian masuk ke halaman utama

Path $2=$ A $0-$ A $1-$ A2 - A4 - A5 - A6

Keterangan Path 2 : admin memasukkan username dan password salah yang kemudian dikembalikan lagi ke halaman form login.

11) Cyclomatic Complexity

$$
\begin{aligned}
\mathrm{V}(\mathrm{G}) & =\mathrm{E}-\mathrm{N}+2 \\
& =7-7+2=2 \\
\mathrm{~V}(\mathrm{G}) & =\mathrm{P}+1 \\
& =1+1=2
\end{aligned}
$$

Cyclomatic Complexity untuk flowgraph masuk ke halaman utama adalah 2. Nilai 2 menunjukkan prosedur kompleksitas program yang baik dan resiko yang rendah.

b. Pengujian Unggah Data

\begin{tabular}{lc}
\multicolumn{2}{c}{ Tabel 8. Pseudo Code Pengujian Unggah Data } \\
\hline A0 & read(username) \\
\hline A1 & read(file) \\
\hline A2 & if(file) then \\
\hline A3 & request->file \\
\hline A4 & file->excel \\
\hline A5 & if((data=!empty) and(data->count)) \\
\hline A6 & insert_data \\
\hline A7 & if(insert_data=!empty) \\
\hline A8 & truncate(insert_data) \\
\hline A9 & insert(insert_data) \\
\hline A10 & endif \\
\hline A11 & endif \\
\hline
\end{tabular}

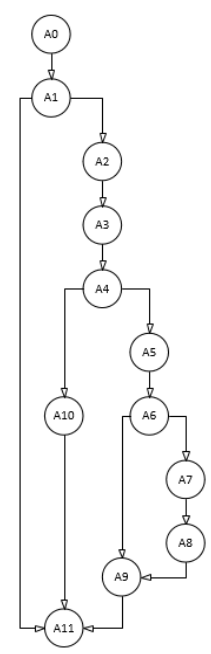

Gambar 4. Flowgraph Pengujian Unggah Data

Flowgraph dari Gambar 4 merupakan hasil dari terjemahan dari pseudo code Tabel 8. Memiliki 3 percabangan, 14 edge dan 12 node.

12) Independent Path

Path $1=\mathrm{A} 0-\mathrm{A} 1-\mathrm{A} 11$

Keterangan Path $1:$ membaca file yang akan di ungah

Path $2=\mathrm{A} 0-\mathrm{A} 1-\mathrm{A} 2-\mathrm{A} 3-\mathrm{A} 4-\mathrm{A} 10-\mathrm{A} 11$

Keterangan Path 2 : membaca file yang akan diunggah dan meminta file dalam bentuk excel 
Path $3=$ A0 - A1 - A2 - A3 - A4 - A5 - A6 - A9 - A11 Keterangan Path 3 : membaca file yang akan diunggah dan meminta file dalam bentuk excel, file excel berisi data dan tidak kosong

Path $4=\mathrm{A} 0-\mathrm{A} 1-\mathrm{A} 2-\mathrm{A} 3-\mathrm{A} 4-\mathrm{A} 5-\mathrm{A} 6-\mathrm{A} 7-\mathrm{A} 8-$ A9 - A11

Keterangan Path 4 : membaca file yang akan diunggah dan meminta file dalam bentuk excel, file excel berisi data dan tidak kosong, jika data masuk maka data sebelumnya akan dikosongkan

13) Cyclomatic Complexity

$$
\begin{aligned}
\mathrm{V}(\mathrm{G}) & =\mathrm{E}-\mathrm{N}+2 \\
& =14-12+2=4 \\
\mathrm{~V}(\mathrm{G}) & =\mathrm{P}+1 \\
& =3+1=4
\end{aligned}
$$

Cyclomatic Complexity untuk proses unggah data adalah 4. Nilai 4 menunjukkan prosedur kompleksitas program yang baik dan resiko yang rendah.

c. Pengujian Unduh Data

Tabel 9 Pseudo Code Pengujian Unduh Data

\begin{tabular}{ll}
\hline A0 & read(data) \\
\hline A1 & if(get->data) then \\
\hline A2 & download_data \\
\hline A3 & else \\
\hline A4 & data empty \\
\hline A5 & endif \\
\hline
\end{tabular}

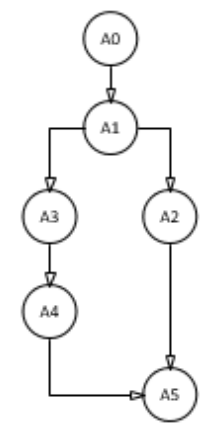

Gambar 5 Flowgraph Pengujian Unduh Data

Flowgraph Gambar 4.27 merupakan hasil terjemahan pseudo code Tabel 4.28 yang memiliki 1 percabangan, 6 edge dan 6 node.

14) Independent Path

Path $1=$ A0 - A1 - A2 - A5

Keterangan Path 1 : jika data ada, maka langsung mengunduh data

Path $2=$ A $0-$ A $1-$ A3 - A4 - A5

Keterangan Path 2 : jika data tidak diunduh maka data kosong

15) Cyclomatic Complexity

$$
\begin{aligned}
\mathrm{V}(\mathrm{G}) & =\mathrm{E}-\mathrm{N}+2 \\
& =6-6+2=2 \\
\mathrm{~V}(\mathrm{G}) & =\mathrm{P}+1 \\
& =1+1=2
\end{aligned}
$$

\begin{tabular}{|c|c|}
\hline A0 & read (Gt $=4)$ \\
\hline$\overline{\mathrm{A} 1}$ & read $(\mathrm{Gb}=3)$ \\
\hline A2 & read $(\mathrm{Tt}=5)$ \\
\hline A3 & read $(\mathrm{Tb}=2)$ \\
\hline A4 & read (biaya [0] [0] =8) \\
\hline A5 & read (biaya [0] [1] =10) \\
\hline A6 & read (biaya [1] [0]=10) \\
\hline A7 & read (biaya [1] [1] =8) \\
\hline A8 & read (gangguan [0] [0] =0) \\
\hline A9 & read (gangguan [0] [1] =0) \\
\hline A10 & read (gangguan [1] [0]=0) \\
\hline A11 & read (gangguan [1] [1]=0) \\
\hline A12 & $\begin{array}{l}\text { if ( (biaya[0][0] < biaya[0][0]) } \\
\quad \text { or (biaya[0][0] < biaya[1][0]) then }\end{array}$ \\
\hline A13 & gangguan $[0][0]=\mathrm{Gt}$ \\
\hline A14 & sisa_teknisi_tasik $=$ Tt - Gt \\
\hline A15 & $\begin{array}{l}\text { if ( (biaya [0] [0]) or (biaya [1] [0])=Gt) } \\
\text { then }\end{array}$ \\
\hline A16 & gangguan[0][1] = sisa_teknisi_tasik \\
\hline A17 & $\begin{array}{l}\text { sisa_gangguan_banjar }= \\
\text { Gb - sisa_teknisi_tasik }\end{array}$ \\
\hline A18 & $\begin{array}{l}\text { gangguan[1][1] } \\
\text { sisa_gangguan_banjar }\end{array}$ \\
\hline A19 & endif \\
\hline A20 & endif \\
\hline A21 & $\begin{array}{l}\text { gangguan_tasik = } \\
\qquad \text { gangguan[0][0] + gangguan[0][1] }\end{array}$ \\
\hline A22 & $\begin{array}{l}\text { gangguan_banjar }= \\
\quad \text { gangguan [1] [0] + gangguan [1] [1] }\end{array}$ \\
\hline A23 & if (gangguan_tasik=Tt) then \\
\hline A24 & $\begin{array}{l}\text { biaya_tasik1 } \\
\text { gangguan [0] [0]*biaya [0] [0] }\end{array}$ \\
\hline A25 & $\begin{array}{l}\text { biaya_tasik2 } \\
\text { gangguan [1] [0]*biaya [1] [0] }\end{array}$ \\
\hline A26 & if(gangguan_banjar=Tb) then \\
\hline A27 & $\begin{array}{l}\text { biaya_banjar1 } \\
\text { gangguan [0] [1]*biaya [0] [1] }\end{array}$ \\
\hline A28 & $\begin{array}{l}\text { biaya_banjar2 } \\
\text { gangguan [1] [1]*biaya [1] [1] }\end{array}$ \\
\hline A29 & endif \\
\hline A30 & endif \\
\hline A31 & write (hitung_total_biaya) \\
\hline
\end{tabular}

Cyclomatic Complexity untuk proses unggah data adalah 2. Nilai 2 menunjukkan prosedur kompleksitas program yang baik dan resiko yang rendah.

d. Pengujian Algoritma Vogel

Tabel 10. Pseudo Code Pengujian Algoritma Vogel 


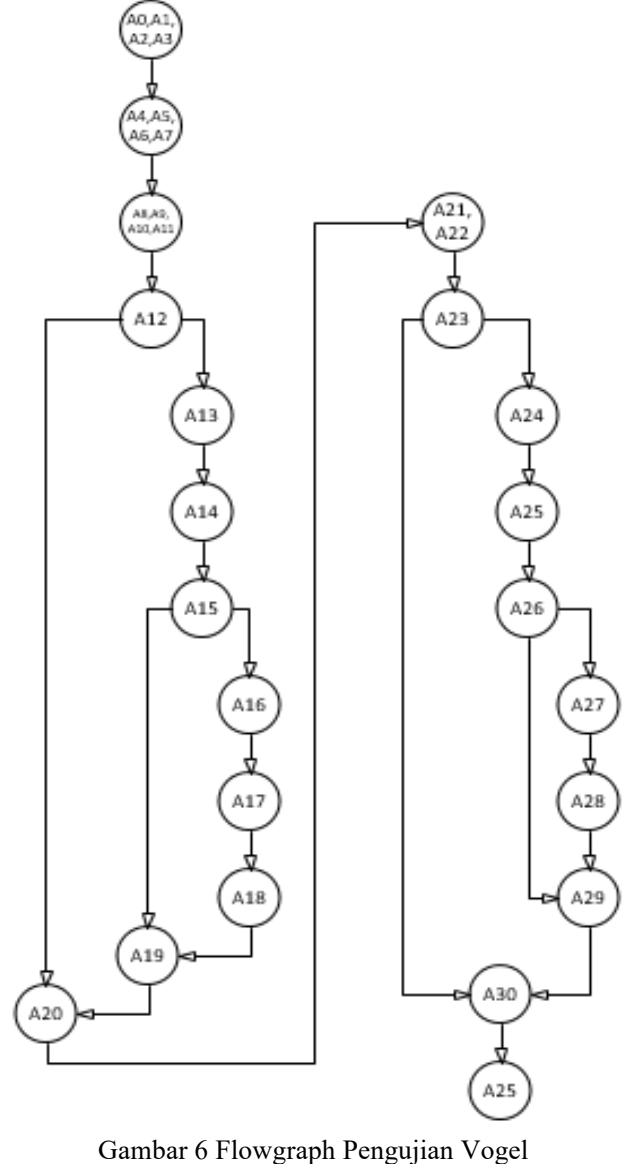

Flowgraph Gambar 6 merupakan hasil terjemahan pseudo code Tabel 10 yang memiliki 5 percabangan, 24 edge dan 21 node.

16) Independent Path

Path $1=\mathrm{A} 0-\mathrm{A} 1-\mathrm{A} 2-\mathrm{A} 3-\mathrm{A} 4-\mathrm{A} 5-\mathrm{A} 6-\mathrm{A} 7-\mathrm{A} 8-$ $\mathrm{A} 9-\mathrm{A} 10-\mathrm{A} 11-\mathrm{A} 12-\mathrm{A} 20-\mathrm{A} 21-\mathrm{A} 22-\mathrm{A} 23-\mathrm{A} 30$ $-\mathrm{A} 31$

Keterangan Path 1 : deklarasi variabel kemudian membandingkan biaya terkecil

Path $2=\mathrm{A} 0-\mathrm{A} 1-\mathrm{A} 2-\mathrm{A} 3-\mathrm{A} 4-\mathrm{A} 5-\mathrm{A} 6-\mathrm{A} 7-\mathrm{A} 8-$ $\mathrm{A} 9$ - A10 - A11 - A12 - A13 - A14 - A15 - A19 - A20 - A21 - A22 - A23 - A30 - A31

Keterangan Path 2 : deklarasi variabel kemudian membandingkan biaya terkecil dan mengisi sel gangguan area Tasikmalaya

Path $3=\mathrm{A} 0-\mathrm{A} 1-\mathrm{A} 2-\mathrm{A} 3-\mathrm{A} 4-\mathrm{A} 5-\mathrm{A} 6-\mathrm{A} 7-\mathrm{A} 8-$ $\mathrm{A} 9-\mathrm{A} 10-\mathrm{A} 11-\mathrm{A} 12-\mathrm{A} 13-\mathrm{A} 14-\mathrm{A} 15-\mathrm{A} 16-\mathrm{A} 17$ - A18 - A19 - A20 - A21 - A22 - A23 - A30 - A31

Keterangan Path 3 : deklarasi variabel kemudian membandingkan biaya terkecil dan mengisi sel gangguan area Tasikmalaya. Jika teknisi sudah memenuhi gangguan maka pindah ke sel berikutnya

Path $4=\mathrm{A} 0-\mathrm{A} 1-\mathrm{A} 2-\mathrm{A} 3-\mathrm{A} 4-\mathrm{A} 5-\mathrm{A} 6-\mathrm{A} 7-\mathrm{A} 8-$ $\mathrm{A} 9-\mathrm{A} 10-\mathrm{A} 11-\mathrm{A} 12-\mathrm{A} 20-\mathrm{A} 21-\mathrm{A} 22-\mathrm{A} 23-\mathrm{A} 24$ - A25 - A26 - A29 - A30 - A31

Keterangan Path 4 : deklarasi variabel kemudian membandingkan biaya terkecil dan mengisi sel gangguan area Tasikmalaya. Jika gangguan tasik sama dengan jumlah gangguan maka proses hitung biaya dimulai.

Path $5=\mathrm{A} 0-\mathrm{A} 1-\mathrm{A} 2-\mathrm{A} 3-\mathrm{A} 4-\mathrm{A} 5-\mathrm{A} 6-\mathrm{A} 7-\mathrm{A} 8-$ $\mathrm{A} 9$ - A10 - A 11 - A12 - A20 - A21 - A22 - A23 - A24 - A25 - A26 - A28 - A29 - A30 - A31

Keterangan Path 5: deklarasi variabel kemudian membandingkan biaya terkecil dan mengisi sel gangguan area Tasikmalaya. Jika gangguan banjar sama dengan jumlah gangguan maka proses hitung biaya dimulai.

17) Cyclomatic Complexity

$$
\begin{aligned}
\mathrm{V}(\mathrm{G}) & =\mathrm{E}-\mathrm{N}+2 \\
& =24-21+2=5 \\
\mathrm{~V}(\mathrm{G}) & =\mathrm{P}+1 \\
& =4+1=5
\end{aligned}
$$

Cyclomatic Complexity untuk proses unggah data adalah 5. Nilai 5 menunjukkan prosedur kompleksitas program yang baik dan resiko yang rendah.

1. Black Box Testing

a. Pengujian Login

\begin{tabular}{clll}
\multicolumn{4}{c}{ Tabel 11 Pengujian Login } \\
\hline No. & Data Masukan & \multicolumn{1}{c}{ Hasil } & Kesimpulan \\
\hline 1 & Username : & Masuk sebagai user & {$[\sqrt{ }]$ Diterima } \\
& 147006239 & 147006239 & {$[$ Ditolak } \\
& Password : & & \\
& 147006239 & & \\
\hline
\end{tabular}

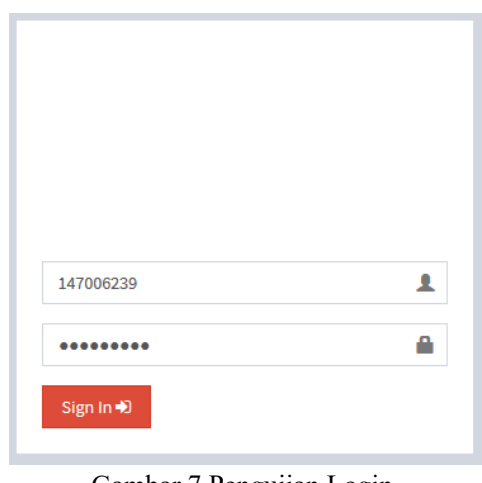

Gambar 7 Pengujian Login

b. Pengujian Unggah Data

\begin{tabular}{cllll}
\multicolumn{5}{c}{ Tabel 12 Pengujian Unggah Data } \\
\hline No. & Data Masukan & \multicolumn{1}{c}{ Hasil } & Kesimpulan \\
\hline 1 & File ekstensi .xlsx & File tersimpan & ke & {$[\sqrt{ }]$ Diterima } \\
& Laporan & Data & database & {$[$ Ditolak } \\
& Access $\quad$ Point & & \\
& Januari 2018 & & \\
\hline
\end{tabular}

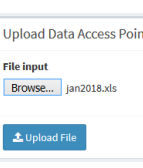

Gambar 8 Pengujian Unggah Data

c. Pengujian Unduh Data

Tabel 13 Pengujian Unduh Data

\begin{tabular}{cllrl}
\hline No. & Data Masukan & \multicolumn{2}{c}{ Hasil } & \multicolumn{1}{c}{ Kesimpulan } \\
\hline 1 & Pengguna & Data & berhasil & {$[\sqrt{ }]$ Diterima } \\
& mengunduh data & $\begin{array}{l}\text { diunduh } \\
\text { database }\end{array}$ & dari & {[} \\
& & & \\
\hline
\end{tabular}




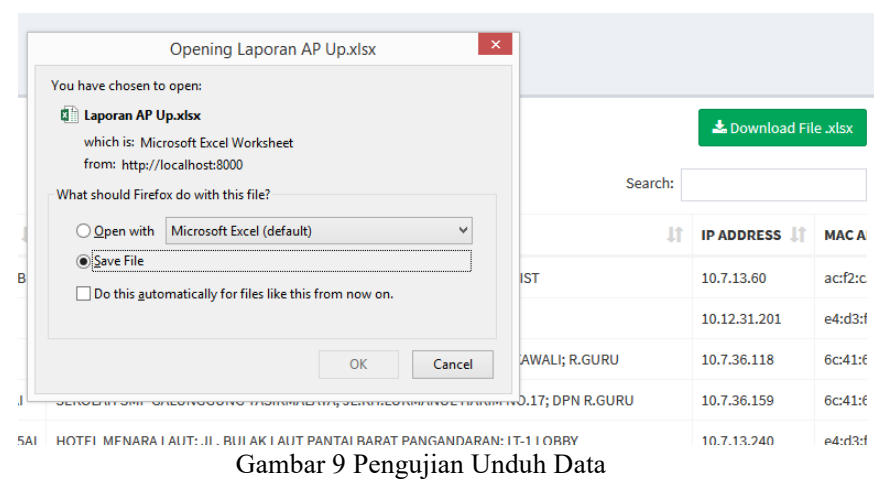

d. Pengujian Klasifikasi Data

Tabel 14 Pengujian Klasifikasi Data

\begin{tabular}{ccll}
\hline No. & Data Masukan & \multicolumn{1}{c}{ Hasil } & Kesimpulan \\
\hline 1 & Query MySQL & Data telah & {$[\sqrt{ }]$ Diterima } \\
& & diklasifikasikan & {[} \\
& & \\
& & \\
& & kerdasarkan \\
& & \\
\hline
\end{tabular}

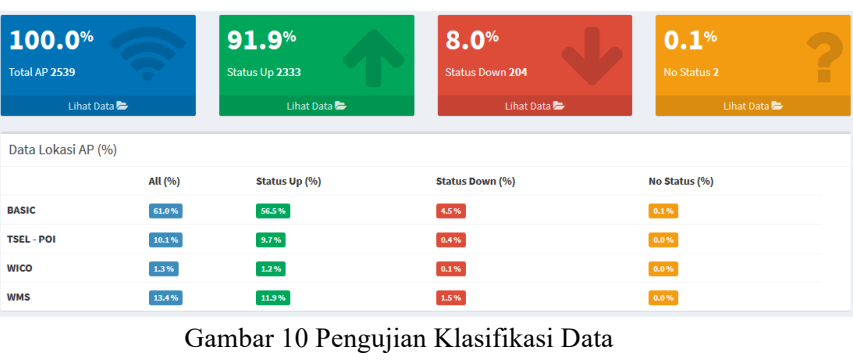

e. Pengujian Algoritma Vogel

Tabel 15 Pengujian Algoritma Vogel

\begin{tabular}{ccll}
\hline No. & Data Masukan & \multicolumn{1}{c}{ Hasil } & Kesimpulan \\
\hline 1 & Data RSK Down & Hasil perhitungan & {$[1 \sqrt{ }]$} \\
& & $\begin{array}{l}\text { sama dengan hasil } \\
\text { perhitungan } \\
\text { manual }\end{array}$ & Diterima \\
& & {[] Ditolak } \\
\hline
\end{tabular}

Metode Vogel Approximation Method

\begin{tabular}{|c|c|c|}
\hline & CANGCUAN TASIK & GANGCUAN BANJAR \\
\hline TEKNISI TASIK & 8 & 10 \\
\hline TEKNISI BANJAR & 10 & 8 \\
\hline Gangguan & 4 & 3 \\
\hline
\end{tabular}

Gambar 11 Pengujian Algoritma Vogel

\section{KESIMPULAN}

Dari hasil penelitian dapat diambil kesimpulan

1. Penerapan algoritma transportasi Vogel Approximation Method berhasil diterapkan dengan hasil perhitungan manual maupun menggunakan program.

2. Perbandingan dengan metode transportasi lainnya seperti metode Barat Laut dan metode Biaya Terendah menghasilkan hasil yang sama namun dengan cara berbeda. Cara yang lebih mudah yaitu dengan menggunakan metode Biaya Terendah namun untuk hasil lebih kecil dengan menggunakan metode Vogel Approximation Method, hanya saja dengan menggunakan metode Vogel Approximation Method lebih rumit.

3. Pengujian white box menunjukkan prosedur kompleksitas program yang baik dan resiko yang rendah dengan rata - rata nilai cyclomatic complexity kurang dari 10.

\section{DAFTAR PUSTAKA}

[1] Arifin, Aridhanyati. "Model Transportasi Untuk Masalah Pendistribusian Air Minum (Studi Kasus PDAM Surakarta)". Jurnal Teknomatika Vol. 7 No.1: $1-10,2014$.

[2] Maharisna, Dimas Bhirawa, Mochammad Al Musadieq, and Heru Susilo. "Analisis Dan Desain Sistem Informasi Transportasi Dengan Metode Vogel's Approximation (Studi Kasus pada UD. Sumber Jaya Grosir Malang)". Jurnal Administrasi Bisnis Vol. 43 No. 2: 19 - 28. 2017.

[3] Simbolon, Lolyta Damora, Marihat Situmorang, and Normalina Napitupulu. "Aplikasi Metode Transportasi Dalam Optimasi Biaya Distribusi Beras Merah (RASKIN) Pada Perum Bulog Sub Divre Medan”. Saintia Matematika Vol. 02, No. 03: 299 311. 2014.

[4] Siang, Jok Jek. Riset Operasi Dalam Pendekatan Algoritmis Edisi 2. Yogyakarta: C. V Andi Offset. 2014.

[5] Indrajani. Database Design. PT. Elex Media Komputindo. 2017.

\section{BIODATA PENULIS}

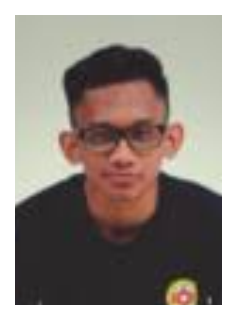

Muhammad Anwari

Mahasiswa Teknik Informatika Fakultas

Teknik Universitas Siliwangi

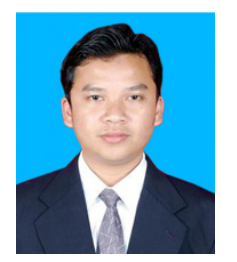

Husni Mubarok

Dosen Informatika Fakultas Teknik Universitas Siliwangi

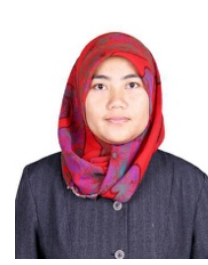

Heni Sulastri

Dosen Informatika Fakultas Teknik Universitas Siliwangi 